\title{
The Contribution of Supervisors to Doctoral Students in Doctoral Education: A Qualitative Study
}

\author{
Kazim Celik \\ Faculty of Education, Pamukkale University, Denizli, Turkey \\ Email: kazimcelik@gmail.com
}

Received November $28^{\text {th }}$, 2012; revised December $30^{\text {th }}$, 2012; accepted January $12^{\text {th }}, 2013$

\begin{abstract}
In this study, it was aimed to analyze supervisor-student relationship in the doctoral education based on views of students. For this reason, research assistants having completed doctoral education and got $\mathrm{PhD}$ title were asked what the contributions of their supervisors were and what kind of problems they experienced in doctoral education. Considering academic advising process, it was intended to shed a light on both formal and information sides of supervisor-student relationship. As a design of the study, qualitative case study method was used. In the light of the aim of the study, "semi-structured data collection form", one of the qualitative data collection tools, was used to collect the data. The data gained from 19 research assistants having completed their $\mathrm{PhD}$ degrees in the past 36 months were analyzed with content analysis. The past/ongoing contribution of supervisors to their students' education were classified under the themes of contribution to their personal development, contribution to academic development, contribution to professional development, and contribution to intellectual development. The students, being in intimate relationship with their supervisors, emphasize positive contributions of supervisors. However, the students, not being in an intimate relationship, underline the negative characteristics of their supervisors. Few of the participants utter ongoing contribution of supervisors. This study analyzes dimensions for the contribution of supervisors to students in doctoral education, and the experiences of students in these dimensions. In this regard, academicians who are supervisors or will be supervisors are expected to benefit from the study.
\end{abstract}

Keywords: Doctorate; Postgraduate; Supervisor; Qualitative Study

\section{Introduction}

Considering major functions, universities are responsible for education-instruction, knowledge generation and dissemination of this knowledge. In the historical development, the significance order of these functions has varied. Knowledge as the main input features function of producing knowledge in universities in the process of globalization. It is one of the basic aims in universities to produce information systematically. As a universal fact, doctoral education is the highest level of postgraduate studies. In the doctoral education, students are expected to develop ability of doing original research about their subjects. Furthermore, it is aimed for students to gain some qualifications such as adapting to the developments in the field, and knowing and evaluating themselves (Kennedy, 1999; Wood \& Vella, 2000; Poock, 2001). In this sense, the PhD is recognized internationally as an award for published or publishable original research evaluated on the basis of a thesis, and the purpose of doctoral education is to educate and train competent, reliable, and self-directed research scientists having a strong sense of scientific integrity. The person holding $\mathrm{PhD}$ should also have the knowledge, abilities, perspectives and understanding to be capable of self-directed work that is satisfactory to others in the field. Therefore, the holder of a $\mathrm{PhD}$ is highly qualified professional of maturity and intelligence who has acquired analytical intelligence and problem solving skills that will eventually allow him or her to carry out independent scientific work (Vella, 2000). In doctoral education as the process of training faculty members, it is highly vital for students aiming for academic career to internalize the issues such as learning teaching, academic mechanisms and responsibility perception in a high level (Coffıeld \& Williamson, 1997; Turker, 1997; Pace \& Kuh, 1998; Kennedy, 1999; Ince \& Korkusuz, 2006).

In doctoral education, students lead a two-phased relationship. In the first phase, this relationship is with the faculty members giving the lectures before students start to write their theses. Then, they study one-to-one with their supervisors along thesis process in the second phase. Ender, Winston and Miller (1984) define thesis supervision as a systematic process between student and supervisor envisaged for students to achieve their academic, career and personal objectives. Similarly, Pearson and Kayrooz (2004) also define research supervision as a facilitative process requiring support and challenge. Academic advising is one of the great tools promoting intellectual, personal and social development of students (Crockett, 1985). The relationship process between student and supervisor, being under the responsibility of both and continuing in a multi-faceted way, is a decision process which enables students to understand their maximum education potential through communication and knowledge exchange with the supervisors (Habley \& Crockett, 1988). As the supervisors interact with candidates in planning and programming of the work, and in setting and keeping the deadlines, they represent the most important external influence in the learning and developments of doctoral candidates (Vella et al., 2000: p. 212). Phillips and Pugh (2005: p. 147) summarize what students should expect: written work to be read in advance, constructive criticism, good knowledge of 
the research area, an exchange of ideas, supervisor to act as a role model, supervisor to teach the skills of research, short-term goal setting that feeds into longer-term objectives, healthy and helpful "psychological contract". When these expectations were considered, the student-supervisor relationship has the potential of being wonderfully enriching and productive; however, it can also be extremely difficult and personally devastating (Dinham \& Scott, 1999).

The studies in the field indicate that individual relationships between doctoral supervisors and doctoral students are of vital importance for the doctoral project (Golde, 2000; Kam, 1997; Marsh et al., 2002; McAlpine \& Norton, 2006). Considering the students preparing doctoral theses, the relationship that starts as a master-apprentice relationship goes through a colleague relationship after completion of the theses. Regarding this point, thesis process and supervisor-student relationship are highly important. Such a relationship is assumed to be pedagogically effective as it has been said for students to provide development and independence. In this sense, this relationship needs to be based on collaboration and discussion more than being hierarchic (Belcher, 1994; Cakici, 2006). According to Know \& McGovern (1988), the most significant characteristics of a supervisor are trustworthiness, competency, willingness to share knowledge, giving objective feedback, enabling students to develop, establishing direct contact with all subjects about students, and being straightforward. To this list, Burgaz \& Senturk (2007) have added some characteristics such as being directive, being an observer and a controller, being accessible, giving constructive suggestions for students, and answering questions in a clear and understandable way. Denicolo (2004) also stated that favorable features of supervisors are being creditable, motivating and encouraging students, being knowledgeable and sharing. Advisors should have listening ability, promote discussion, give continuous feedback and support students. In addition to these, they should be enthusiastic, warm and thoughtful. For Seagram et al. (1998), favorable characteristics of supervisors are professionalism, friendliness and having supportive stance (Mainhard et al., 2009).

In higher education, academic advising has been accepted as one of the substantial tools to promote intellectual, personal and social development of students. On the condition that this relationship progress well, students do not learn just ideas and techniques, but it might be a mutual intellectual development. Thus, they adopt new perspectives and a deep knowledge as a result of this relationship (Connell, 1985). Within this process, liabilities of a supervisor might be defined as getting students to adopt the ability to comment on scientific issues by examining them in a broad and deep perspective, and determining the steps that let them make syntheses (Tosun, 2001). A supervisor gives a wide variety of intellectual support and help, develops critical thinking skills of students and provides them with qualified knowledge about their studies (Rugg \& Petre, 2004). The advancements in science and technology also contributed a lot to student-supervisor relationship. The contribution of supervisors to students about implementing recent applications in science and technology is a new field to be scrutinized in the context of student-supervisor relationship.

In a host of countries, standards developments were effectuated about academic advising at an international level and some suggestions were put forward. One of these carrying out standard developments is UNESCO. According to UNESCO (2002); academic advising, on the basis of learning and teach- ing mission of higher education institutions, is an integration of curriculum, pedagogy, a group of learning outcomes and terminal relations. In other words, academic advising is to synthesize educational experiences of students by handling the subject with all parameters in order for them to practice their desires, abilities and lives out of the campus and time.

According to UNESCO (2002), academic advising fulfills the following objectives: 1) to assist students in developing educational plans that are consistent with their life goals, 2) to provide students with accurate information about academic progression and degree requirements, 3) to assist students in understanding academic policies and procedures, 4) to help students access campus resources that will enhance their ability to be academically successful, 5) to assist students in overcoming educational and personal problems, 6) to identify systemic and personal conditions that may impede student academic achievement and developing appropriate interventions, 7) to review and use available data about students' academic and educational needs, performance, aspiration and problems, 8) to increase student retention by providing a personal contact that students often need and request, thereby connecting them to the institution.

The documents developed by the National Academic Advising Association (NACADA) and its subsidiary organization, National Academic Advising Association, and CAS Standards and Guidelines in Academic Advising Programs, developed by the Council for the Advancement of Standards in Higher Education (CAS) guideline efficacious framework for academic advising.

On the other hand, no study could be found about a national framework of standards in Turkey despite being such a significant issue at an international level. Also, it can be said that there is a lack of studies about these standards in academic milieu. As a common result of previous studies, in Turkey, there are significant problems in the relationship between students and supervisors. These studies mainly emphasized the student-supervisor relationship on the basis of theses. According to these studies, some negative results were concluded as follows: 1) research skills of students were not developed (Koklu \& Buyukozturk, 1999); 2) learning teaching was not emphasized (Akpinar-Wilsing \& Paykoc, 2004); 3) supervisors were so busy to guide students, they did not have the command of the subject, they did not communicate with students and left them alone, they lacked the field knowledge (Ince \& Korkusuz, 2006; Sayan \& Aksu, 2005); 4) students were alone to determine the subjects of their theses and develop assessment tools (Bakioglu \& Gurdal, 2001).

When the literature was analyzed, it was realized that studies focused on carrying out academic studies, and time and management of these studies. Academic advising is a process formally aiming to accomplish an academic study. However, it is more than a relationship between the student and the supervisor through a thesis study. In the process of thesis supervision, the only product is not the doctoral thesis. There is also a mutual informal learning in one-to-one relationship. It needs to emphasize that this learning is not one-way but mutual. These informal outcomes have significant effects on the lives of academicians who are at the beginning of their academic careers.

It is really important for researchers and practitioners to ascertain the contributions of doctoral supervisors to students and the problems in this process. In this sense, academicians, who are supervisors or potential supervisors, are expected to benefit 
from this study that classify the contributions of supervisors to students and analyze the experiences in this process. There is a dearth of studies in this subject so it is required to do research with $\mathrm{PhD}$ candidates to be able to make them receive a quailfied education in future.

This study aims to analyze the student-advisor relationship in doctoral education on the basis of the views of students. In this respect, the study intends to find out both formal and informal aspects of the student-supervisor relationship in an academic advising process.

\section{Method}

Case study, a qualitative study method, was used in this study. Also, an embedded single case inquiry was applied. As the case in the study was approached in a holistic way as a unit, a holistic single case inquiry was used (Yildirim \& Simsek 2005).

\section{Study Group}

The study group was comprised of 19 faculty members who work at different faculties of Pamukkale University with the title of Dr. Res. Asst. who had completed their PhD degrees in the preceding 36 months. 8 of the participants got their $\mathrm{PhD}$ degrees in the field of science and 11 of them in social sciences field. There are 9 female and 10 male participants. The title of supervisors as follows: 14 Prof. Dr., 3 Assoc. Prof. Dr. and 2 Asst. Prof. Dr. The distribution of universities in doctoral education is as follows: 7 from Gazi University, 3 from Pamukkale University, 2 from Dokuz Eylul University and 5 from other different universities.

\section{Instruments and Data Collection}

In the light of the aim for the study, a qualitative semistructured data collection form was used. The semi-structured data collection form was created by benefiting from the literature review, and depending on the standards and core values of National Academic Advising Association (NACADA, 2011) in the USA. It was finalized on the basis of the views of supervisors and students. Semi-structured data collection form consisted of 5 questions expecting participants to account for the contributions of academic and thesis supervisors to their "General Education", "Personal Developments", "Use of Science and Technological Applications", "Professional Preparation" and "Intellectual Development". Through e-mail, the forms were sent to 30 participants accepting to fill out the forms in the phone conversation and 23 of them resent the forms. 4 of the participants were excluded as they exceeded 36 months limit after $\mathrm{PhD}$ and 19 of the data forms were considered in the analysis.

\section{Data Analysis}

The data gained from the study were analyzed with content analysis to conceptualize the data with the aim of finding out the experiences and meanings out, and determine the themes that can define the matter of fact (Yildirim \& Simsek, 2005). In the interview period, the written documents were read by taking the literature into consideration. The long answers of participants were abridged by the researcher on the condition that they did not change the meaning of original views. The codes of this qualitative research were identified by the researcher and one expert through the concepts at the first step. The expert and the researcher reported their impression on interviewing coding sheet independently (Gay, 1987). Following this step, these codes were compared and tested for reliability analysis.

For the second step, the themes were identified according to the similarities and differences among the codes. The subcategories were outlined regarding their meanings with the help of the studies in the field. As a result of this process, the number of themes and subcategories were determined as 4 and 13 respectively. To be able to keep confidential, the participants were tagged as Participant Social Sciences (PSS) and Participant Science (PS), and were enumerated.

Comparison of the codes and reliability: The researcher and the expert firstly coded $25 \%$ of the data for the reason of reliability and comparing the codes. The reliability was computed through a comparison between the codes of the researcher and the expert. Through descriptive statistics, the numbers of "agreement" and "disagreement" were identified following the markings of the researcher and the expert. When the researcher and the expert both marked the same theme or didn't mark any theme for a certain question, this was accepted as "agreement between raters". On the other hand, it was accepted as "disagreement" when the researcher and the expert opted for the different themes in the same question but the marking of the researcher was based on.

$$
=\frac{\mathrm{T} \text { (Agreement percent) }}{\text { Agreement }(\mathrm{Na})+\text { Disagreement }(\mathrm{Nd})} \times 100
$$

The reliability of the research was figured out using the preceding formula. Overall, it is stated that the inter-rater reliability is provided when the result of the formula is above $70 \%$ of the quotes check-coded (Gay, 1987; Miles \& Huberman, 1994). Following this reliability analysis, the reliability percent of interview questions was computed and the reliability was found to have varied between $80 \%$ and $95 \%$ as a result of the comparison of interview question codes between the researcher and the expert. This result was regarded as reliable for the research as it was higher than $70 \%$.

To ensure the validity and reliability of the study, some supplementary precautions (Yildirim \& Simsek, 2005) were also taken. For the purpose of using data variation techniques, the documents investigating the supervisor-student relationship were analyzed to use as data sources. Furthermore, some of the main results in the data analysis were shared with some of the participants to consider their views and these views were used to benefit from. As a last step, the researchers in the field were asked about their opinions on the results.

The results were presented in a descriptive style. There could be found direct excerpts but the long answers of participants were abridged by the researcher on the condition that they did not change the meaning of original views. In addition to that, the findings about the themes were accounted for and commented (Yildirim \& Simsek, 2005).

\section{Findings}

As a result of the content analysis in the research whose study group was Dr. research assistants having completed their $\mathrm{PhD}$, the past/ongoing contribution of supervisors to their stu- 
dents' education were classified under the themes of contribution to their personal development, contribution to academic development, contribution to professional development, and contribution to intellectual development. The views of the students about contributions of supervisors were presented as themes and subcategories in Table 1.

\section{The Views about the Contribution to Personal Development}

According to Table 1, the theme about the contribution of supervisors to students consists of two subcategories as making students know about other societies in the world and teaching necessary abilities for contact and collaboration with others. The participant views underlining these subcategories were stated below.

When the views about making students know about other societies in the world were considered, most of the students mentioned negative contributions of their supervisors as well as positive contributions. The participants stressed positive contributions of supervisors about making students about other societies in the world as; "My supervisor gave general information about other societies in the world" (PS5), "As my thesis supervisor had studied abroad for doctorate and post doctorate, he/she shared all his/her experiences he/she gained about information, cultural life and communication styles of other societies in the world" (PS8). One of the negative views is "In spite of all my effort and academic kindness, we couldn't communicate in an effective and healthy way. As my supervisor refused to realize me, I completed my doctoral education with a single-sided work ethic and platonic work passion" (PSS5).

When the views about teaching necessary abilities for contact and collaboration with others were considered, the participants put more emphasis on this subcategory of the theme, contribution to personal development. The participants remarked the positive contribution of their supervisors about teaching necessary abilities for contact and collaboration with others as they follow; "My supervisor provided for me with necessary skills about contacting and collaborating with others" (PS5), "My supervisor regards receiving support and collaborating with others in researches as an important issue" (KS11), "I have my supervisor to thank as he/she taught me contacting with people and understanding them with the situation they have been in, and looking at the bright side" (PSS4), "I observed that my supervisor adopted a prudent and respectful manner in his/her relations with others" (PSS8), "I learned tolerance and modesty from my supervisor, too” (PS3). One of the participants looks from a different perspective as "My supervisor has an effect on me being suspicious about people in communication and collaboration. I can say that I learned not to share lots of things as people work competitively in working environment. My supervisor underlined that the research subjects should not be shared because there is a possibility for them to be stolen by others" (PSS2).

About giving opportunities for students to develop themselves, the responses of participants were insightful; "My supervisor had exemplary character” (PSS9), "My supervisor was sharing gains such as knowledge, culture and so on with the students" (PSS3), "My supervisor gave hope and confidence" (PS11), "I developed my study understanding the theorist I studied on thanks to my supervisor" (PSS2), "My supervisor supported me to understand different points of view and develop my own understanding by canalizing me to follow the classes of other instructors” (PS7). The excerpts stating negative situations are as follow; "I cannot say that my supervisor had so much effect on me. There is no limit for academic advising and our supervisor was managing many students for supervision at the same time. I learned to be patient because the time my supervisor gave me to read and evaluate my writings took two or three times more than he/she did” (PSS6), “As research assistants are responsible for covering their supervisors' classes, assessing exams, making preparations for classes, they do not have enough time to enable their professional developments” (PSS1).

\section{The Views about the Contribution to Academic Development}

For the theme of the contribution of a supervisor to academic

Table 1.

The themes and subcategories as a result of the analysis.

\begin{tabular}{|c|c|c|c|}
\hline Theme & Subcategories & $\mathrm{f}(\mathrm{PSS})$ & $\mathrm{f}(\mathrm{PS})$ \\
\hline \multirow{3}{*}{$\begin{array}{l}\text { Contribution to personal } \\
\text { development }\end{array}$} & To make students know about other societies in the world & 9 & 5 \\
\hline & To teach necessary abilities for contact and collaboration with others & 10 & 7 \\
\hline & To give opportunities for students to develop themselves & 7 & 6 \\
\hline \multirow{3}{*}{$\begin{array}{c}\text { Contribution to academic } \\
\text { development }\end{array}$} & To provide experience for students to do research and publish them & 11 & 8 \\
\hline & To make students attend congress, workshop and conferences & 11 & 8 \\
\hline & To give high level information about research subjects & 10 & 7 \\
\hline \multirow{3}{*}{$\begin{array}{c}\text { Contribution to professional } \\
\text { development }\end{array}$} & To introduce recent developments and applications in science and technology & 9 & 8 \\
\hline & To teach job or working ability (Tutoring) & 7 & 5 \\
\hline & To plan their careers & 9 & 7 \\
\hline \multirow{4}{*}{$\begin{array}{c}\text { Contribution to intellectual } \\
\text { development }\end{array}$} & To teach writing, presenting and speaking & 10 & 8 \\
\hline & To give high level thinking skills and develop them & 9 & 6 \\
\hline & To teach about ethical standards and scientific values & 11 & 9 \\
\hline & To increase knowledge about different philosophy, culture and lifestyles & 9 & 6 \\
\hline
\end{tabular}


development of a student, subcategories are defined as providing experience for students to do research and publish them, making students attend congresses, workshops and conferences, and giving high level information about research subjects. The excerpts underlying these subcategories are given below.

The following sentiments about providing experience for students to do research and publish them were typical positive ones in this regard; "My supervisor encouraged me to publish papers and he/she contributed to me about how research projects are developed and evaluated" (PS6), "My supervisor has great contributions about how to prepare articles, proceedings and so on" (PS3), "A proceeding at international level and an article were published based on my master thesis" (PSS4), "My supervisor would tell us to never stop researching and writing" (PSS8). There is no one expressing a negative idea about their supervisors.

When the subcategory about making students attend congress, workshop and conferences is considered, the positive excerpts about the supervisor were; "My supervisor would analyze and criticize my writings constructively before my seminars, proceedings and other presentations" (PS3), "My supervisor encouraged me to attend congresses abroad as he/she followed recent seminars and studies. Although I used to have some doubts if I could speak English, he/she insisted me how it is crucial to attend seminars and workshops abroad" (PSS2), "My supervisor shared ideas and thoughts about scientific meetings, scientific publications and so on. She/he contributed to us to attend seminars he/she organized. His/her positive attitudes in this matter provided us to be self-sufficient" (PSS3), "Even after my doctoral education finished, my supervisor encouraged me to attend workshops voluntarily or compulsorily and this results in positive scientific developments" (PSS8). Some participants also stated negativity and expectations with brief expressions; "Unfortunately, my supervisor did not contribute to me" (PSS5), "My supervisor does not have a significant contribution to me” (PS2), “... I solve my problems with my own efforts and studies” (PSS13).

The views about giving high level information about research subjects are both negative and positive. The excerpts reflecting positive views are; "My supervisor had a great contribution for me to develop in my field. She/he played an active role for defining the subjects of my two theses" (PSS4), "I made all contradictions in terms clear thanks to my supervisor. She/he also contributed to me about understanding English definitions and concepts in the literature" (PSS2). The negative excerpts were mainly based on the complaints about not providing high level information about research subjects as they follow; "My academic and thesis supervisors suggested that I did my own research instead of giving direct information about my major" (PSS7), "The contribution of my supervisor to my general education is to direct me on my doctoral research subject. I carried out the research on this subject and we exchanged ideas about experimental part of my thesis" (PS4), "My supervisor was working hard in two different universities throughout my thesis process. Due to time limitation and busyness, she/he had some times when she/he could not supervise me" (PSS8).

\section{The Views about the Contribution to Professional Development}

For the theme of the contribution of a supervisor to professional development of a student, subcategories are defined as introducing recent developments and applications in science and technology, teaching job or working ability, and planning their careers. The participant views underlining these subcategories are stated below.

The participants shared positive views about introducing recent developments and applications in science and technology as follow; "A helpful process started when my supervisor shared his/her experiences. She/he informed me about new research subjects and approaches in the field" (PSS8), "My supervisor transferred me all the information about the developments in the field and new applications" (PS6), "My supervisor definitely shares recent books in the field" (PSS2). While positive views outnumbered negative views, there are also some negative views highlighting lack of technology knowledge of supervisors as follow; "The technological developments are effective for my field in recent years, but I can say that my supervisor could not contribute to me considering that she/he also met technology recently" (PSS13), "I think I contributed a lot to my supervisor about the usage of internet and communication technologies" (PSS2), "Although my supervisor did not have contribution about informatics, I developed myself throughout my career in accordance with my needs" (PS4).

Some favorable views about teaching job or working ability are as follow; "My supervisor made some suggestions about my professional life based on her/his experiences" (PS6), “As I gained knowledge and good manners in my doctoral study, my supervisor contributed to me about being self-confident and encouraged" (PSS10), "My supervisor had a great contribution for me to contact with some companies and select the tools used in experimental studies" (PS3), "My supervisor canalized me to the current subjects and she/he wanted the results of applications to be tested with different methods in terms of reliability of results" (PSS9). One of the participants expressed his/her different understanding as; "As my supervisor did not have much knowledge about project studies, she/he encouraged us to do research and give information to her/him. She/he contributes to us to become self-sufficient thanks to her/his positive attitudes" (PSS3).

The excerpts about planning career subcategory emphasize indirect positive contributions more than direct ones. Some views related to this subcategory are given as they follow; "My supervisor has contributed from the beginning to right now" (PSS4), "My supervisor informed me about the educational career I had in my mind” (PS7), "My thesis supervisor was very informative about my professional career" (PSS11), "My supervisor contributed not directly but in an indirect way with the materials she/he provided, professional courses, seminars and books she/he recommended” (PS11), "My supervisor supported me with her/his high motivation” (PSS9), "My supervisor focused on the thesis in career planning" (PSS8), "My supervisor has still some contributions in my career planning. We still work together" (PS1). The negative views about career planning were so clear and these views are; "My supervisor did not contribute to me about personal-professional preparation and career planning" (PSS1), "I do not think my supervisor has a contribution” (PSS2), "There is no contribution about career planning” (PS4), "We did not plan anything about my professional career together" (PS9), "I expected from my supervisor to help me contact with the professionals abroad, and provide me to do research and work with them. However, she/he did not make any suggestions about this issue” (PSS7). 


\section{The Views about the Contribution to Intellectual Development}

For the theme of the contribution of a supervisor to intellectual development of a doctoral student, subcategories are defined as teaching writing, presenting and speaking abilities, giving high level thinking skills and develop them, teaching about ethical standards and scientific values, increasing knowledge about different philosophy, culture and lifestyles. Some of the reflections by the participants are presented below.

The positive views about the subcategory of teaching writing, presenting and speaking abilities were; "In this sense, my supervisor contributed much. My major is related with analytical and logical thinking, synthesizing, and solving qualitative problems” (PSS2), “Joint studies in different fields, especially in philosophy, affected my personal life concept in a positive way" (PS7), "My supervisor gave opportunities to me to discuss about the knowledge she/he taught to me" (PSS7), "My thesis supervisor has positive effects on me in developing how to solve qualitative problems and synthesize them" (PSS11), "With a few instructors, my supervisor contributed to me on academic thinking, evaluation, critical thinking, and raising an objection when necessary” (PS6).

The views about increasing knowledge about different philosophy, culture and lifestyles manifest positive contributions of supervisors in this sense. The students expressed this contributions as; "My supervisor taught to me to respect for different cultures" (PSS3), "My supervisor told us to approach people with an understanding manner even if our views are different" (PSS2), "Thanks to my supervisor, I learned the life style, cultural understanding and perspectives of high education and income families in the south of the USA towards eastern societies such as Turkey" (PS11), "I got the opportunity to see all cities in Turkey with the projects we prepared together” (PSS4), "My supervisor has some contributions on me in thinking the situations in different ways” (PS8).

\section{Discussion}

The views about the past or ongoing contribution of supervisors to doctoral education of students were classified under the themes of personal, academic, professional and intellectual development.

One of the main themes is the contribution to personal development. Based on personal development, communication and collaboration with others are two main fields to know about other societies in the world. When the views about the subcategory of making students know about other societies in the world were considered, positive contributions focused on the terms of "giving information-sharing information". The views about the subcategory of teaching necessary abilities for contact and collaboration with others are replete with favorable statements of many participants in terms of personal development. The terms around this title differ as taking others' support, cooperation, understanding people, looking at the bright side, being prudent to respectful manner, tolerance and modesty. On the other hand, the negative statements gather around suspicion, rivalry and lack of sharing. Cullen et al. (1994) suggested that good supervisors be warm and friendly; supportive, positive; open-minded, ready to compensate his/her knowledge mistakes; well-organized, ready, and eager and determined to do research. Considering the supervisors in the study in this regard, most of the students described their supervisors with similar character- istics. However, a substantial number of students stated they could not find these traits in their supervisors. While the participants were emphasizing on the characteristics such as being exemplary, reassuring, directive, supportive, and having a spirit of sharing, they defined doing nonsense work as the obstacle for development.

About the views of the subcategory "giving high level information about research subjects, the contributions and expectations concentrated on "providing necessary information" and "directing students". The first views were about contribution to development, determining thesis subject, and teaching terms and concepts. For this contribution, it can be stated that supervisors had prevailing role. The second view manifested that the supervisors gave suggestions instead of giving direct information, exchange information and set the students free. This view can be seen as an approach enabling students discuss and tell their comments throughout the research. Students find out their true identity with the theses they prepare and present. In this sense, thesis is the peak point of scientific production. The first outcomes of the institutes are theses as the result of researches (Ozturk, 2008). These outcomes are shared with the academia thanks to scientific publications. The views about the subcategory of providing experience for students to do research and publish them focused on encouraging and contributing in this regard. Even if it cannot be seen officially in the documents, there are a host of studies in the doctoral education process of students. These studies are mostly carried out with the help of their supervisors. Furthermore, supervisors are more effective about publication process of students as they are accepted as first author in theses of students in many documents about the criteria for promotion of academicians. In order to help students attend congresses, workshops and meetings, the methods supervisors applied are analysis, constructive criticism, sharing ideas and thoughts, and enforcement. These methods were evaluated as positive contributions by supervisors. Some participants also stated that their supervisors did not contribute and they overcame difficulties with their own efforts. Corbett \& Wright (1994) suggest that a good supervisor be interested in current academic organizations and exemplary character for their students.

Professional development provides both to gain knowledge, and develop and update this knowledge or skill. In this regard, the aim of professional development is to gain information, skill and behaviors necessary for the field, and compensate for pre-service training. Information and communication technologies affect professional developments in two ways. Firstly, they need to integrate information and communication technologies to their professions. Secondly, information and communication technologies are utilized as a tool in order to meet the needs of professional development (Odabası \& Kabakcı, 2007).

When the views were considered in the subcategory of introducing recent developments and applications in science and technology, the students made use of information and communication technologies as a means of integration with their professions. The views in this category underline lack of technology background of supervisors, and contribution of students to supervisors. It is an accentuated issue for students to show their own effort for their development. It is evident that young generations get on well with technology. This situation becomes clear as much as advances in technology improve. In this sense, the relationship between the supervisor and the student becomes a mutual process more by means of technological ad- 
vancements.

To teach job or working ability (Tutoring), supervisors provide individual tutoring assistance when students have difficulties in understanding some issues. This individual tutoring assistance gives students opportunity to answer unanswered questions (Tan, 2005; Topping, 2000). For the subcategory of teaching or working ability, following concepts were emphasized; "benefiting from experience", "enhancing knowledge and etiquette", "gaining self-confidence", "contacting with business world", "selecting suitable devices for experiments", "directing at current issues" and "testing experimental findings in different techniques”. It is expected for students to have individual tutoring assistance for the subjects they have difficulty in. However, some students learn to be self-sufficient when supervisors directed them to do research about the subjects their knowledge is limited.

Career planning involves 1) evaluating own environment of a person in a right way, 2) defining his/her interests, 3) enhancing his knowledge and abilities, 4) discovering his/her strong and weak sides, 5) being aware of the opportunities in the institution, and using these opportunities, 6) setting short, medium and long term targets about his/her career, and deciding on the actions to realize these targets. Career developing is to realize all the plans related to career step by step using his/her education, skills, personal development, job networks, and job experience (Karmer, 2011). In this sense, career planning and developing is a vital process in doctoral education. For the positive views, the relationship between the supervisor and the student about career planning and developing is based on subject of thesis. The techniques used in career developing are; "informing", "directing”, "professional trainings", "seminars and book recommendations", "motivating”. It is a prerequisite to put an emphasis on continuity of supervisor-student relationship as it is considered as a positive effect resulted from its being process-based. However, a limited number of students expressed the supports of their supervisors continued after graduation. Negative excerpts clearly show that students do not have expectations, and supervisors do not contribute to students in this context.

An effective academic advising is about ongoing intellectual development of doctoral students more than writing a thesis. It is highly crucial to 1) define conferences and seminars they can attend, 2) write earlier and publish their writings, 4) direct, inform and encourage students about finding fellows, 5) determine necessary sources. An effective supervisor also makes it easier for students to contact with professionals in the field and this helps them develop. In this sense, a supervisor meets professionals in his/her field as earlier as possible, and tries to send the best work of doctoral candidates to research organizations and academicians (Wadee, Keane, Dietz, \& Hay, 2010). The views of students are usually positive about teaching writing, presenting and speaking. The examples in this regard are as follow; 1) linking ideas in a scientific paper, 2) relating among findings and literature review, 3) teaching presentation and rhetoric skills, 4) taking a role as a presenter at panel, symposium and other organizations, 5) arousing interests in the fields of literature, philosophy, sociology and mathematics.

In the supervisor-student relationship, the views were mostly positive in the subcategory of teaching about ethical standards and scientific values. The positive excerpts reflects some terms such as 1) directing at interdisciplinary research, 2) freedom of scientific expression, 3) going beyond dogmas using methods of philosophy, 4) the need for supervisors to be fair, respectful, participative and model. On the other hand, there could be seen negative excerpts such as "I realized what I should not do when I become supervisor" and "solutions based on title and bureaucratic power".

High level thinking skill, being a subcategory of intellectual development, is a way of thinking based on doing research, questioning, and reasoning. In this sense, it requires consistency, relation and extensive intellectual activities to base results on findings (Haladayna, 1997; Lipman, 1994; Paul, 1995; Aslan, 2011). The contribution of interdisciplinary studies as a subcategory of giving high level thinking skills is highly important. It also stood out that supervisors provided opportunities to discuss about the findings. The other terms were also mentioned in this subcategory such as thinking in analytic and logical way, solving quantitative problems and developing ability to synthesize, academic thinking, evaluation, and critical approach.

Doctoral education is a process that includes teaching different philosophies, cultures, and lifestyles on the way of becoming a world citizen. The views about this category were expressed as follow; "respect different cultures", "sensibility to different points of views", "looking from different perspectives", "learning life styles, cultures and likes of people” and "travelling around different parts of countries". The views about increasing knowledge about different philosophy, culture and lifestyles indicate positive contributions of supervisors.

When it is considered in a holistic way, the words such as "being directive" and "communication" are emphasized for academic advising stated as a process. Students expect to establish an intimate relationship with supervisors in order to be provided with guidance and communication in academic advising process. The students, being in this kind of relationship with their supervisors, emphasized positive contributions of supervisors. However, the students, not being in an intimate relationship, underlined the negative characteristics of their supervisors. In this sense, studies into students' reasons for non-completion in the UK found that the most frequently cited, $30 \%$ of the cases, was problems with supervision (Buckley \& Hooley, 1988). The study of Wrench \& Punyanunt (2004) indicated that the role of the relationship between student and supervisor unique in academic advising, too. Guven, Kerem, \& Ersoy (2009) also concluded that students mind a healthy relationship between student and supervisor.

Furthermore, the students expressed their expectations for a direct and effective direction with the emphasis on "giving opportunities to discuss gained knowledge”. The expectations from supervisors "sharing their experiences and directing students" were stated by 6 participants studying at social sciences and all participants studying at science. Seagram et al. (1998) mentioned that students studying at science need to talk to their supervisors more than the students studying at the social sciences. This study also corroborates with Seagram's study regarding expectations of science students from their supervisors. This situation might result from that they need more individual advising as their fields are about technical issues. The students see this relationship as a flowing process for the contribution from supervisors to students. This situation also emerges in the usage of technology. The students often stress the contribution of them to supervisors regarding technology. The reason for this emphasis might result from the perception that supervisors should be more qualified in all fields. However, the supervisor-student relationship is a mutual exchange process at the 
same time. Another reason for this perception might be that students grew up in a teacher-centered education system. According to other studies, lack of an intimate relationship between supervisor and student might result in that the length of doctoral studies extends, and quality of thesis decreases (Eriksson, 2001; ASHE Report, 2001; Heath, 2002; Cakıcl, 2006).

\section{Conclusion}

Consequently, it can be suggested that supervisors contribute to students about their personal, academic, professional and intellectual developments. While many students focus on past contributions, few of them utter ongoing contribution of supervisors. From a holistic point of view, "direction" and "communication" terms are of vital importance in thesis supervision process. The students, being in intimate relationship with their supervisors, emphasize positive contributions of supervisors. However, the students, not being in an intimate relationship, underline the negative characteristics of their supervisors. In supervisor-student relationship, it can be said that students contribute to their supervisors about the use of statistics and technology.

The contributions or expectations of supervisors to students in doctoral education concentrate on some terms such as 1) research subject and information about various subjects, 2) communication and collaboration skills, 3) development of students, 4) participation in congress, workshops and publications, 5) adaptation to advancements in science and technology, 6) job or working ability, 7) career planning, 8) high level thinking skills, and 9) ethical standards scientific values. The students who learn about these terms emphasize the relationship as a positive one while the students whose expectations are not met consider this relationship as a negative one.

\section{Acknowledgements}

I would like to express my special thanks of gratitude to Assoc. Prof. Dr. Ekber Tomul who supported with his views and directions, and field specialist Cennet Celik Urun who was very supportive in publication process.

\section{REFERENCES}

Akpınar-Wilsing, N., \& Paykoc, F. (2004). Gelecegin ogretim elemanlarının ogretimde planlama, etkili ogretim ve degerlendirmeyle ilgili ihtiyacları: Bir ornek olay calısması [The needs of future faculty members about planning, effective teaching, and evaluation in instruction: A case study]. Education and Science, 29, 71-82.

ASHE Report (2001). Institutional culture and socialization: Differences among academic programs. ASHE ERIC Higher Education Report, ED 450710, 28, 55-87.

Aslan, C. (2011). Soru sorma becerilerini gelistirmeye donuk ogretim uygulamalarinin ogretmen adaylarinin soru olusturma becerilerine etkisi. [The effect of instruction applications aiming for students to develop the skills about asking questions on the skills of preparing questions.] Education and Science, 36, 236-248.

Bakioglu, A.,\& Gurdal, A. (2001). Lisansustu tezlerde danisman ve ogrencilerin Rol Algıları: Yonetim icin gostergeler [Role perceptions of students and advisors about postgraduate theses: indicators for management]. Hacettepe University the Journal of Education, 21, 9-18.

Belcher, D. (1994). The apprenticeship approach to advanced academic literacy: Graduate students and their mentors. English for Specific Purposes, 13, 23-34. doi:10.1016/0889-4906(94)90022-1

Buckley, P. J., \& Hooley, G. J. (1988). The non-completion of doctoral research in management: Symptoms, causes and cures. Educational Research, 30, 110-120. doi:10.1080/0013188880300205

Burgaz, B., \& Senturk, I. (2007). The advisers' and advisees' views about the master's thesis advisers' behaviors of communication. Humanity\& Social Sciences Journal, 2, 148-158.

Coffield, F., \& Williamson, B. (1997). The challenges facing higher education: Repositioning higher education. Buckingham: Society for Research into Higher Education \& Open University Press,

Connell, R. (1985). How to supervise a PhD. Vestes: Australian Universities Review, 28, 38-41.

Corbett, P., \& Wright, D. (1994). Issues in the selection and training of mentors for school-based primary initial teacher training mentoring. In D. Mcintyre, H. Hagger, \& M. Wilkin (Eds.), Perspectives on schoolbased teacher education. London: Kogan Page Limited.

Council for the Advancement of Standards in Higher Education (2012). CAS professional standards for higher education. URL (last checked 8 August 2012).

http://www.cas.edu/getpdf.cfm?PDF=E864D2C4-D655-8F74-2E647 CDECD29B7D0

Crockett, D. S. (1985) . Academic advising. In L. Noel, R. Levitz, \& D. Saluri (Eds.), Increasing student retention (pp. 224-263). San Francisco, CA: Jossey-Bass.

Cullen, D., Pearson, M., Saha, L. J., \& Spear, R. H. (1994). Establishing effective PhD supervision. Canberra: AGPS.

Cakıcı, A. C. (2006). Turizm alaninda lisansustu tez hazirlayan ogrencilerin danisman ogretim uyelerini ve danisman ogretim uyelerinin de ogrencilerini degerlendirmesi. [An evaluation of students by advisors and of advisors by students writing up postgraduate theses in tourismfield.] Dokuz Eylul Universitesi Sosyal Bilimler Enstitusu Dergisi, 8, 74-104

Denicolo, P. (2004). Doctoral supervision of colleagues: Peeling off the veneer of satisfaction and competence. Studies in Higher Education, 29, 693-707. doi:10.1080/0307507042000287203

Dinham, S., \& Scott, C. (1999). The doctorate: Talking about the degree. Sydney: University of Western Sydney.

Ender, S. C., Winston, R. B., \& Miller, T. K. (1984). Academic advising reconsidered. In R. B. Winston Jr., T. K. Miller, S. C. Ender, T. J. Grites, \& Associates (Eds.), Developmental academic advising (pp. 3-34). San Francisco,CA: Jossey-Bass.

Eriksson, K. (2001). Starting postgraduate education at a small university. Proceedings of Postgraduate Education in Europe, 4-5 May 2001, Linköping: University of Linköping.

Gay, L. R. (1987). Educational research competencies for analysis and application (3rd ed.). London: Merrill Publishing Company.

Golde, C. M. (2000). Should I stay or should I go? Student descriptions of the doctoral attrition process. Review of Higher Education, 23, 199-227.

Guven, B., Kerem, E. A., \& Ersoy, E. (2007). Lisansustu egitim sırasında karsılasılan sorunlara iliskin ogrenci goruslerinin belirlenmesi. [Defining student views regarding problems in postgraduate study.] Lisansustu Egitim Sempozyumu Bildiri Kitabı, 308-318.

Habley, W. R., \& Crockett, D. S. (1988). The third ACT national survey of academic advising. In W. R. Habley (Ed.), The status and future of academic advising (pp. 11-76). Iowa City, IA: American College Testing Program.

Haladyna, T. M. (1997). Writing test items to evaluate higher order thinking. Boston, MA: Allyn and Bacon

Heath, T. (2002). A quantitative analysis of $\mathrm{PhD}$ students' views of supervision. Higher Education Research \& Development, 21, 41-53. doi:10.1080/07294360220124648

Ince, M. L., \& Korkusuz, F. (2006). Lisansustu egitim hedeflerini gelistirmede ogrenci ogretim uyesi etkilesimi: Bir disiplinin farklı universitelerde ve farkl disiplinlerin bir universitedeki durumu proje raporu. [Student and faculty member interaction in developing postgraduate study objectives: A project report of a discipline at different universities and of different fields at the same university]. TUBITAK Proje No: 104K093

Kam, H. (1997). Style and quality in research supervision: The supervisor dependency factor. Higher Education, 34, 81-103.

Karmer (2011). Kariyer planlama ve gelistirme el kitabı [Handbook of 
career planning and development]. Turgut Ozal Universitesi Kariyer Planlama Uygulama ve Arastırma Merkezi. URL (last checked 4 August 2012).

http://www.turgutozal.edu.tr/kariyermerkezi/contents/kariyermerkezi /files/Kariyer_kitpacik_v1.pdf

Kennedy, D. (1999). Academic duty. (5th ed.). Dubuque: Wm. C. Brown Publishers.

Knox, P., \& McGovern, T. (1988). Mentoringwomen in academia. Teaching of Psychology, 15, 39-41. doi:10.1207/s15328023top1501 10

Koklu, N., \& Buyukozturk, S. (1999). Egitim bilimleri alanında ogrenim goren lisansustu ogrencilerin arastırma yeterlilikleri konusunda ogretim uyelerinin gorusleri. [The views of faculty members on research competency of postgraduate students studying at educational sciences.] Education and Science, 23, 18-28.

Lipman, M. (1994). Thinking in education. Cambridge: Cambridge University Press.

Mainhard, T., Van der Rijst, R., Van Tartwijk, J., \& Wubbels, T. (2009). A model for the supervisor-Doctoral student relationship. High Education, 58, 359-373. doi:10.1007/s10734-009-9199-8

Marsh, H. W., Rowe, K. J., \& Martin, A. (2002). PhD students' evaluations of research supervision issues, complexities, andchallenges in a nation wide australian experiment in bench marking universities. The Journal of Higher Education, 73, 313-348. doi:10.1353/jhe.2002.0028

McAlpine, L., \& Norton, J. (2006). Reframing our approach to doctoral programs: An integrative framework for action and research. Higher Education Research \& Development, 25, 3-17. doi:10.1080/07294360500453012

Miles, M. B., \& Huberman, M. A. (1994). An expanded sourcebook qualitative data analysis. London: Sage Publication.

NACADA (2011). AS Standards for academic advising. URL (last checked 8 August 2012). http://www.cas.edu/getpdf.cfm?PDF=E864D2C4-D655-8F74-2E647 CDECD29B7D0

Odabasi, H. F., \& Kabakci, I., (2007). Ogretmenlerin mesleki gelisimlerinde bilgi ve iletisim teknolojileri. [The significance of information and communication technologies in professional development of teachers.] Uluslararasi Ogretmen Yetistirme Politikaları ve Sorunları Sempozyumu Bildiriler Kitabis. 39-43, 12-14 Mayis 2007, Baku: Azerbaycan.

Ozturk, N. (2008). Akademik kimlik ve etik. [Academic identity and ethic.] Akademik Dizayn Dergisi, 2, 47-56.

Pace, R. C, \& Kuh, G. D. (1998). College students experiences questionnaire (4th ed.). Bloomington, IN: Indiana University.

Paul, R. (1995). Critical thinking: Basic questions and answers. In J. Wilsenve, \& A. J. A. Binker (Eds.) Critical thinking: How to prepare students for a rapidly chancing world (pp.489-500). Santa Rosa, CA: Foundation for Critical Thinking.

Pearson, M., \& Kayrooz, C. (2004). Enabling critical reflection on research supervisory practice, International Journal for Academic
Development, 9, 99-116. doi:10.1080/1360144042000296107

Poock, M. C. (2001). A model for integrating professional development in graduate education. College Student Journal, 35, 345-352.

Rugg, G., \& Petre, M. (2004). The unwritten rules of PhD research. New York: Open University Press

Sayan, Y., \& Aksu, H. (2005). Akademik personel olmadan lisansustu egitim yapan bireylerin karsılastıkları sorunlar uzerine nitel calısma. Dokuz Eylul Universitesi-Balıkesir Universitesi [A qualitative study on students studying postgraduate degree without being academic staff]. Buca Egitim Fakultesi Dergisi, 17, 59-65

Seagram, B. C., Gould, J., \& Pyke, W. (1998). An investigation of gender and other variables on time to completion of doctoral degrees. Research in Higher Education, 39, 319-335.

Tan, S. (2005). Ogretimde planlama ve degerlendirme. [Planning and evaluation in education.] Ankara: Ani yayincilik.

Topping, K. (2000). Tutoring, UNESCO, international academy of education international bureau of education, Educational practices series-5 Switzerland. URL (last checked 8 August 2012). http://www.ibe.unesco.org/fileadmin/user_upload/archive/publicatio ns/EducationalPracticesSeries.pdf/ prac05e.pdf

Tosun, I. (2001). Bilim adami yetistirme toplantisi acilis konusmasi. Bilim adamı yetistirme lisansustu egitim TUBA bilimsel toplantı serileri: 7. [The opening speech in the meeting of raising scientists. Raising scientists, postgraduate study, and scientific congress series of TUBA.] TUBA Yaymları

Turker, R. K. (1997). Bilim adamı yetistirme, dunyada ve Turkiye'de lisansustu egitim (pp: 21-34). Ankara: Turkiye Bilimler Akademisi, Bilim Adamı Yetistirme Toplantısı, Lisansustu Egitim Konferansı Bildirisi,

UNESCO (United Nations Educational, Scientific and Cultural Organization) (2002). The role of student affairs and services in higher education: A practical manual for developing, implementing and assessing student affairs programmes and services. Paris: UNESCO.

Vella, F., de Meis, L., Mehler, A. H., Rombauts, W., White, H. B., \& Wood, E. J. (2000). Recommendations of the committee on education of the international union of biochemistry and molecular biology. Standards for the Ph.D. degree in the molecular biosciences. Biochemical Education, 28, 2-11.

Wadee, A. A., Keane, M., Dietz, T., \& Hay, D. (2010). Effective PhD supervision mentorship and coaching. Amsterdam: Rozenberg Publishers

Wood, E. J., \& Vella, F. (2000). IUBMB updates Ph.D. standards. BioEssays, 22, 771-773.

Wrench, J. S., \& Punyanunt, N. M. (2004). Advisee-advisor communication: An exploratory study examining interpersonal communication variables in the graduate advisee-advisor relationship. Communication Quarterly, 52, 224-236. doi:10.1080/01463370409370194

Yildirim, A. \& Simsek, H. (2005). Sosyal bilimlerde nitel arastırma yontemleri. [Qualitative research techniques in social sciences.] (5th ed.). Ankara: Seckin Yayınevi. 